\title{
Cardiac magnetic resonance imaging analysis in STEMI: quantitative or still visual?
}

\author{
E. E. van der Wall $\cdot$ J. J. Bax $\cdot$ J. H. Reiber
}

Received: 23 April 2010/Accepted: 24 April 2010/Published online: 8 May 2010

(C) The Author(s) 2010. This article is published with open access at Springerlink.com

Cardiac magnetic resonance imaging (CMR) has long been recognized as an accurate and reliable means of evaluating cardiac anatomy and ventricular function. Considerable progress has been made in the field of CMR, providing accurate evaluation of left ventricular function parameters in coronary artery disease, heart failure, hypertrophic cardiomyopathy, and many other cardiac diseases [1-12]. Stress first-pass contrast-enhanced myocardial perfusion CMR can be used to detect subendocardial ischemia and recent studies have demonstrated the high diagnostic accuracy of stress myocardial perfusion CMR for detecting significant coronary artery disease [13-16]. Magnetic resonance angiography has been introduced as a method that can provide visualization of all three major coronary arteries, coronary anomalies, coronary bypasses and the aorta within a single threedimensional acquisition [17-19]. CMR has become the first choice imaging modality in complex congenital heart disease [20-26], imaging great vessels,

This is an editorial comment to the article of Husser et al. (doi: 10.1007/s10554-010-9601-8).

E. E. van der Wall $(\bowtie) \cdot$ J. J. Bax

Department of Cardiology, Leiden University Medical Center, P.O. Box 9600, Leiden, The Netherlands

e-mail: e.e.van_der_wall@lumc.nl

\section{J. H. Reiber}

Department of Radiology, Leiden University Medical

Center, P.O. Box 9600, Leiden, The Netherlands and evaluation of therapy such as cardiac resynchronization therapy [27-38].

Over the past years, contrast-enhanced CMR has been used to visualize the transmural extent of myocardial infarction with high spatial resolution [39-45]. Infarcted myocardium appears hyperenhanced compared with normal myocardium when imaged by a late enhancement MRI technique with the use of T1-weighted sequence after injection of gadolinium chelates. Late gadolinium-enhanced CMR can clearly delineate subendocardial infarction and the transmural extent of delayed enhancement potentially predicts functional outcome after revascularization in acute myocardial infarction and chronic ischemic heart disease [46-49].

In the current issue of the International Journal of Cardiovascular Imaging, Husser et al. [50] compared quantitative assessment of contrast CMR with visual analysis in patients with ST-segment elevation myocardial infarction (STEMI) for predicting reduced ejection fraction and major adverse cardiac events such as death, re-infarction, and re-admission for heart failure. The authors studied 192 patients who underwent CMR at 1 week and 6 months after a sustained STEMI. Three quantitative indices (initial slope, maximal signal intensity and contrast delay in first-pass imaging) and two visual perfusion indices (hypo-enhancement in first-pass and microvascular obstruction in late enhancement imaging) were evaluated. Quantification of infarct mass and visual assessment of the extent of transmural necrosis was 
also performed on the basis of the standard 17segment model. At 6 months, 69 patients showed reduced ejection fraction; during follow-up of mean 655 days, 20 major adverse cardiac events occurred. Quantification of the perfusion images was very timeconsuming and proved not superior to visual perfusion analysis to predict reduced ejection fraction and/ or major adverse cardiac events. Similarly, quantification of infarct size was not superior to visual assessment of the extent of transmural necrosis. In multivariate analysis, only visual assessment of extent of transmural necrosis predicted reduced ejection fraction and major adverse cardiac events. The authors concluded that visual analysis of CMR in patients with STEMI is not time-consuming and predicts reduced ejection fraction and major adverse cardiac events comparable to quantitative analysis. The extent of transmural necrosis turned out to be the strongest parameter. The present study is the first to investigate whether a complete quantitative analysis of a post-infarct-CMR study would be more accurate than a complete visual analysis of microvascular perfusion and myocardial necrosis to predict late ejection fraction and major adverse cardiac events in a large group of patients with STEMI. The data confirm previous findings from the same group showing that neither qualitative nor quantitative myocardial perfusion nor time-consuming quantification of infarct mass provides incremental predictive value over visual assessment of transmural necrosis [51-53].

Despite these interesting findings, it should be realized that quantification of perfusion and infarct size offers the potential advantages of being less operator-dependent, more objective, and more accurate. At present, CMR offers several acquisition techniques for precise and highly reproducible assessment of global and regional ventricular function, flow, and perfusion at rest and under pharmacological or physical stress conditions [54-56]. Moreover, CMR allows quantification of blood flow over the valves, and automatic vessel wall contour detection and quantification of wall thickness of invivo MR images of the human aorta [57-59]. Recent advances in hardware and software have resulted in strong improvement of image quality and in a significant decrease in the required imaging time for each of these acquisitions. However, quantitative image analysis often still relies on manual tracing of contours in the images, being indeed time-consuming thereby limiting the clinical applicability of CMR for routine analysis. Methods for automated and robust assessment of the parameters of cardiac function, blood flow and morphology, are still being developed to overcome the limitations associated with manual image processing [60]. Until these issues are fully solved, the present study clearly indicates that, for prediction of late cardiac events in patients with STEMI, a comprehensive visual approach may suffice in routine clinical practice.

Open Access This article is distributed under the terms of the Creative Commons Attribution Noncommercial License which permits any noncommercial use, distribution, and reproduction in any medium, provided the original author(s) and source are credited.

\section{References}

1. van der Wall, Vliegen HW, de Roos A, Bruschke AV (1995) Magnetic resonance imaging in coronary artery disease. Circulation 92:2723-2739

2. Bavelaar-Croon CD, Kayser HW, van der Wall EE et al (2000) Left ventricular function: correlation of quantitative gated SPECT and MR imaging over a wide range of values. Radiology 217:572-575

3. Bax JJ, Lamb H, Dibbets P et al (2000) Comparison of gated single-photon emission computed tomography with magnetic resonance imaging for evaluation of left ventricular function in ischemic cardiomyopathy. Am J Cardiol 86:1299-1305

4. Posma JL, Blanksma PK, van der Wall EE, Hamer HP, Mooyaart EL, Lie KI (1996) Assessment of quantitative hypertrophy scores in hypertrophic cardiomyopathy: magnetic resonance imaging versus echocardiography. Am Heart J 132:1020-1027

5. Pluim BM, Beyerbacht HP, Chin JC et al (1997) Comparison of echocardiography with magnetic resonance imaging in the assessment of the athlete's heart. Eur Heart J 18:1505-1513

6. Pluim BM, Chin JC, De Roos A et al (1996) Cardiac anatomy, function and metabolism in elite cyclists assessed by magnetic resonance imaging and spectroscopy. Eur Heart J 17:1271-1278

7. van der Wall EE, den Hollander W, Heidendal GA, Westera G, Majid PA, Roos JP (1981) Dynamic myocardial scintigraphy with 123I-labeled free fatty acids in patients with myocardial infarction. Eur J Nucl Med 6:383-389

8. Braun S, van der Wall EE, Emanuelsson S, Kobrin I (1996) Effects of a new calcium antagonist, mibefradil (Ro 405967), on silent ischemia in patients with stable chronic angina pectoris: a multicenter placebo-controlled study. The mibefradil international study group. J Am Coll Cardiol 27:317-322

9. Schuijf JD, Bax JJ, Shaw LJ et al (2006) Meta-analysis of comparative diagnostic performance of magnetic resonance 
imaging and multislice computed tomography for noninvasive coronary angiography. Am Heart J 151:404-411

10. Ypenburg C, van der Wall EE, Schalij MJ, Bax JJ (2008) Imaging in cardiac resynchronisation therapy. Neth Heart J 16:S36-S40

11. van Rugge FP, van der Wall EE, Bruschke AV (1992) New developments in pharmacologic stress imaging. Am Heart J 124:468-485

12. van Rugge FP, Holman ER, van der Wall EE et al (1993) Quantitation of global and regional left ventricular function by cine magnetic resonance imaging during dobutamine stress in normal human subjects. Eur Heart J 14:456-463

13. Pluim BM, Lamb HJ, Kayser HW, Leujes F et al (1998) Functional and metabolic evaluation of the athlete's heart by magnetic resonance imaging and dobutamine stress magnetic resonance spectroscopy. Circulation 97: $666-672$

14. van Rugge FP, van der Wall EE, Spanjersberg SJ et al (1994) Magnetic resonance imaging during dobutamine stress for detection and localization of coronary artery disease. Quantitative wall motion analysis using a modification of the centerline method. Circulation 90:127-138

15. Schuijf JD, Bax JJ, van der Wall EE (2007) Anatomical and functional imaging techniques: basically similar or fundamentally different? Neth Heart J 15:43-44

16. Nemes A, Geleijnse ML, van Geuns RJ et al (2008) Dobutamine stress MRI versus threedimensional contrast echocardiography: it's all black and white. Neth Heart J 16:217-218

17. Vliegen HW, Doornbos J, de Roos A, Jukema JW, Bekedam MA, van der Wall EE (1997) Value of fast gradient echo magnetic resonance angiography as an adjunct to coronary arteriography in detecting and confirming the course of clinically significant coronary artery anomalies. Am J Cardiol 79:773-776

18. Hoogendoorn LI, Pattynama PM, Buis B, van der Geest RJ, van der Wall EE, de Roos A (1995) Noninvasive evaluation of aortocoronary bypass grafts with magnetic resonance flow mapping. Am J Cardiol 75:845-848

19. Langerak SE, Vliegen HW, de Roos A et al (2002) Detection of vein graft disease using high-resolution magnetic resonance angiography. Circulation 105:328-333

20. Rebergen SA, Ottenkamp J, Doornbos J, van der Wall EE, Chin JG, de Roos A (1993) Postoperative pulmonary flow dynamics after Fontan surgery: assessment with nuclear magnetic resonance velocity mapping. J Am Coll Cardiol 21:123-131

21. Portegies MC, Schmitt R, Kraaij CJ et al (1991) Lack of negative inotropic effects of the new calcium antagonist Ro 40-5967 in patients with stable angina pectoris. J Cardiovasc Pharmacol 18:746-751

22. Groenink M, Lohuis TA, Tijssen JG et al (1999) Survival and complication free survival in Marfan's syndrome: implications of current guidelines. Heart 82:499-504

23. Tulevski II, Hirsch A, Sanson BJ et al (2001) Increased brain natriuretic peptide as a marker for right ventricular dysfunction in acute pulmonary embolism. Thromb Haemost 86:1193-1196

24. Niezen RA, Helbing WA, van der Wall EE, van der Geest RJ, Rebergen SA, de Roos A (1996) Biventricular systolic function and mass studied with MR imaging in children with pulmonary regurgitation after repair for tetralogy of Fallot. Radiology 201:135-140

25. Vliegen HW, van Straten A, de Roos A et al (2002) Magnetic resonance imaging to assess the hemodynamic effects of pulmonary valve replacement in adults late after repair of tetralogy of fallot. Circulation 106:1703-1707

26. Oosterhof T, van Straten A, Vliegen HW et al (2007) Preoperative thresholds for pulmonary valve replacement in patients with corrected tetralogy of Fallot using cardiovascular magnetic resonance. Circulation 116:545-551

27. Bleeker GB, Bax JJ, Fung JW et al (2006) Clinical versus echocardiographic parameters to assess response to cardiac resynchronization therapy. Am J Cardiol 97:260-263

28. Bleeker GB, Holman ER, Steendijk P et al (2006) Cardiac resynchronization therapy in patients with a narrow QRS complex. J Am Coll Cardiol 48:2243-2250

29. van der Laarse A, Kerkhof PL, Vermeer F et al (1988) Relation between infarct size and left ventricular performance assessed in patients with first acute myocardial infarction randomized to intracoronary thrombolytic therapy or to conventional treatment. Am J Cardiol 61:1-7

30. van der Hoeven BL, Pires NM, Warda HM et al (2005) Drug-eluting stents: results, promises and problems. Int $\mathbf{J}$ Cardiol 99:9-17

31. van der Laan A, Hirsch A, Nijveldt R et al (2008) Bone marrow cell therapy after acute myocardial infarction: the HEBE trial in perspective, first results. Neth Heart J 16:436-439

32. van der Wall EE, Siebelink HM, Bax JJ (2010) Evaluation of hypertrophic cardiomyopathy: new horizons for CMR? Neth Heart J 18:116-117

33. Bakx AL, van der Wall EE, Braun S, Emanuelsson H, Bruschke AV, Kobrin I (1995) Effects of the new calcium antagonist mibefradil (Ro 40-5967) on exercise duration in patients with chronic stable angina pectoris: a multicenter, placebo-controlled study. Ro 40-5967 International Study Group. Am Heart J 130:748-757

34. Bleeker GB, Schalij MJ, Boersma E et al (2007) Relative merits of M-mode echocardiography and tissue doppler imaging for prediction of response to cardiac resynchronization therapy in patients with heart failure secondary to ischemic or idiopathic dilated cardiomyopathy. Am J Cardiol 99:68-74

35. Ypenburg C, Sieders A, Bleeker GB et al (2007) Myocardial contractile reserve predicts improvement in left ventricular function after cardiac resynchronization therapy. Am Heart J 154:1160-1165

36. Torn M, Bollen WL, van der Meer FJ, van der Wall EE, Rosendaal FR (2005) Risks of oral anticoagulant therapy with increasing age. Arch Int Med 165:1527-1532

37. Ypenburg C, Schalij MJ, Bleeker GB et al (2007) Impact of viability and scar tissue on response to cardiac resynchronization therapy in ischaemic heart failure patients. Eur Heart J 28:33-41

38. Ypenburg C, Roes SD, Bleeker GB et al (2007) Effect of total scar burden on contrast-enhanced magnetic resonance imaging on response to cardiac resynchronization therapy. Am J Cardiol 99:657-660

39. de Roos A, Matheijssen NA, Doornbos J et al (1990) Myocardial infarct size after reperfusion therapy: assessment with Gd-DTPA-enhanced MR imaging. Radiology 176:517-521 
40. de Roos A, Matheijssen NA, Doornbos J, van Dijkman PR, van Rugge PR, van der Wall EE (1991) Myocardial infarct sizing and assessment of reperfusion by magnetic resonance imaging: a review. Int J Card Imaging 7:133-138

41. van Rugge FP, van der Wall EE, van Dijkman PR, Louwerenburg HW, de Roos A, Bruschke AV (1992) Usefulness of ultrafast magnetic resonance imaging in healed myocardial infarction. Am J Cardiol 70:1233-1237

42. Holman ER, van Jonbergen HP, van Dijkman PR, van der Laarse A, de Roos A, van der Wall EE (1993) Comparison of magnetic resonance imaging studies with enzymatic indexes of myocardial necrosis for quantification of myocardial infarct size. Am J Cardiol 71:1036-1040

43. van der Wall EE, Bax JJ (2008) Late contrast enhancement by CMR: more than scar? Int $\mathrm{J}$ Cardiovasc Imaging 24:609-611

44. van der Wall EE, van Dijkman PR, de Roos A et al (1990) Diagnostic significance of gadolinium-DTPA (diethylenetriamine penta-acetic acid) enhanced magnetic resonance imaging in thrombolytic treatment for acute myocardial infarction: its potential in assessing reperfusion. Br Heart $\mathrm{J}$ 63:12-17

45. van der Wall EE, Heidendal GA, den Hollander W, Westera G, Roos JP (1980) I-123 labeled hexadecenoic acid in comparison with thallium-201 for myocardial imaging in coronary heart disease. A preliminary study. Eur J Nucl Med 5:401-405

46. van Rugge FP, Boreel JJ, van der Wall EE et al (1991) Cardiac first-pass and myocardial perfusion in normal subjects assessed by sub-second Gd-DTPA enhanced MR imaging. J Comput Assist Tomogr 15:959-965

47. Nijveldt R, Beek AM, Hirsch A et al (2008) 'No-reflow' after acute myocardial infarction: direct visualisation of microvascular obstruction by gadolinium-enhanced CMR. Neth Heart J 16:179-181

48. Roes SD, Kelle S, Kaandorp TA et al (2007) Comparison of myocardial infarct size assessed with contrast-enhanced magnetic resonance imaging and left ventricular function and volumes to predict mortality in patients with healed myocardial infarction. Am J Cardiol 100:930-936

49. Larose E, Côté J, Rodés-Cabau J et al (2009) Contrastenhanced cardiovascular magnetic resonance in the hyperacute phase of ST-elevation myocardial infarction. Int J Cardiovasc Imaging 25:519-527
50. Husser O, Bodi V, Sanchis J et al (2010) Head to head comparison of quantitative versus visual analysis of contrast CMR in the setting of myocardial stunning after STEMI: implications on late systolic function and patient outcome. Int $\mathrm{J}$ Cardiovasc Imaging. (Epub ahead of print)

51. Bodi V, Sanchis J, Lopez-Lereu MP et al (2006) Microvascular perfusion 1 week and 6 months after myocardial infarction by first-pass perfusion cardiovascular magnetic resonance imaging. Heart 92:1801-1807

52. Bodi V, Sanchis J, Lopez-Lereu MP et al (2007) Evolution of 5 cardiovascular magnetic resonance-derived viability indexes after reperfused myocardial infarction. Am Heart J 153:649-655

53. Bodi V, Sanchis J, Nunez J et al (2009) Prognostic value of a comprehensive cardiovascular magnetic resonance assessment soon after a first ST-segment elevation myocardial infarction. JACC Cardiovasc Imaging 2:835-842

54. Holman ER, Buller VG, de Roos A et al (1997) Detection and quantification of dysfunctional myocardium by magnetic resonance imaging. A new three-dimensional method for quantitative wall-thickening analysis. Circulation 95: 924-931

55. van der Geest RJ, de Roos A, van der Wall EE, Reiber JH (1997) Quantitative analysis of cardiovascular MR images. Int J Card Imaging 13:247-258

56. van der Geest RJ, Niezen RA, van der Wall EE, de Roos A, Reiber JH (1998) Automated measurement of volume flow in the ascending aorta using MR velocity maps: evaluation of inter- and intra-observer variability in healthy volunteers. J Comput Assist Tomogr 22:904-911

57. van der Geest RJ, Reiber JH (1999) Quantification in cardiac MRI. J Magn Reson Imaging 10:602-608

58. Westenberg JJ, Roes SD, Ajmone Marsan N et al (2008) Mitral valve and tricuspid valve blood flow: accurate quantification with $3 \mathrm{D}$ velocity-encoded MR imaging with retrospective valve tracking. Radiology 249:792-800

59. Janssen JP, Rares A, Tuinenburg JC, Koning G, Lansky AJ, Reiber JH (2010) New approaches for the assessment of vessel sizes in quantitative (cardio-)vascular X-ray analysis. Int J Cardiovasc Imaging 26:259-271

60. Attili AK, Schuster A, Nagel E, Reiber JH, van der Geest RJ (2010) Quantification in cardiac MRI: advances in image acquisition and processing. Int J Cardiovasc Imaging (Epub ahead of print) 